\section{Chemosphere}

Volume 67, Issue 9, April 2007, Pages S36-S47

http://dx.doi.org/10.1016/j.chemosphere.2006.05.088

(c) 2006 Elsevier Ltd All rights reserved
Archimer, archive institutionnelle de l'Ifremer http://www.ifremer.fr/docelec/

\title{
Organochlorinated contaminants in decapod crustaceans from the coasts of Brittany and Normandy (France)
}

\author{
N. Bodin ${ }^{a}$, A. Abarnou ${ }^{\text {a, }}{ }^{\star}$, A.-M. Le Guellec ${ }^{a}$, V. Loizeau ${ }^{a}$ and X. Philippon ${ }^{a}$ \\ a Institut Français de Recherche pour l'Exploitation de la Mer IFREMER, Département Biogéochimie et \\ Ecotoxicologie, Centre de Brest, BP70, 29280 Plouzané, France \\ *: Corresponding author : aabarnou@ifremer.fr
}

\begin{abstract}
:
The contamination and distribution of organochlorinated compounds were considered in three crustacean species (edible crab, Cancer pagurus; spider crab, Maja brachydactyla; velvet swimming crab, Necora puber) from five sites along the coasts of Brittany and Normandy (Western and NorthWestern France). PCBs (16 single congeners), $p p^{\prime}$-DDE and HCB were measured in hepatopancreas, gonads and muscle: in all, 175 samples were analysed. The spider crab was the only species found in the five sampling sites, thus enabling comparison between areas. Specimens from Antifer were much more contaminated ( $\Sigma_{16}$ PCBs in hepatopancreas $=2000-4000 \mathrm{ng} \mathrm{g}^{-1}$ dry weight) than those from other sites (50-1000 $\mathrm{ng} \mathrm{g}^{-1} \mathrm{~d}$.w.). Among all the three species, the spider crab appeared more contaminated by PCBs than the edible crab, by a factor $2-3$, probably in relation with specific differences in their life cycle. There was no difference due to the gender of the species. Within the different analysed tissues, contamination levels increased from muscle to gonads and hepatopancreas in relation with the fat content. A very similar PCB composition was observed in all samples, PCB fingerprints being characterised by the relative importance of the more persistent $\mathrm{PCB}$ congeners: CB153, 138, 180, 187, and 118. Finally, these results were compared to recent food regulations first of maximum marker PCB intake and secondly of maximum dioxin-like PCB intake. By considering the muscle, all samples were far below the regulatory limits; for hepatopancreas and gonads, however, some samples were unfit for human consumption.
\end{abstract}

Keywords: Polychlorobiphenyls; Crustaceans; Normandy; Brittany; France; Human diet 


\section{Introduction}

Organochlorinated contaminants such as Polychlorobiphenyls (PCBs) are examples of widespread chemical compounds of great environmental and health concern. PCBs have given rise to huge amount of works in the last forty years since they have been discovered at trace levels in environmental samples (Jensen, 1966). Thus, they were the subject of many studies concerning their occurrence in water, sediment and more especially in biota. PCBs are currently followed in pollution monitoring programmes like the Réseau National d’Observation de la qualité du milieu marin (R.N.O.) in France (Claisse, 1989, Beliaeff and Smith, 1996), or the Mussel Watch in the USA (O’Connor, 2004). Moreover, the varying physico-chemical properties of the various PCB congeners, depending on the number and position of the chlorine atoms bound to the biphenyl structure, make them interesting compounds in order to understand and to model the distribution and fate of organic contaminants in the environment and trophic web (Connolly, 1991; Mackay and Fraser, 2000; Loizeau et al., 2001). The toxicity of PCBs results from their chlorination pattern. A number of PCBs, which have two or more chlorine atoms in the ortho-position, express a non-dioxinlike toxicity (marker PCBs or M-PCBs). A smaller group of non-ortho and mono-ortho substituted congeners (dioxin-like PCBs or DL-PCBs) elicits similar toxicological effects as 2,3,7,8-TCDD. As for dioxins, TEFs (Toxicity Factor Equivalent) were given to these DLPCB congeners (Ahlborg et al., 1994; Van den Berg et al., 1998) to estimate their TEQ (Toxic Equivalent Quantity). Because of their toxic properties, many studies have been carried out to evaluate PCB and dioxin contamination in food and to characterise the human exposure (Focant et al., 2002; Smith and Gangolli, 2002; Baars et al., 2004; Bordajandi et al., 2004).

To our knowledge, there is very little information on the presence of organochlorinated contaminants in large crustaceans from French waters. However, these species are currently exploited and represent an important economical activity in certain French regions such as Brittany and Normandy. Based on a market basket survey, the French food safety agency reported quite high dioxin levels in crustaceans (AFSSA, 2000) compared to other food items. However, as for other products, the results were expressed on a fat content which appears questionable in the case of very lean products like crustacean meat.

Below are presented the results on organochlorinated contaminants (PCBs, $p p$ '-DDE and HCB) in large crustaceans. The first objective was to estimate the concentration ranges of these compounds in different edible crustaceans from the French coasts. For that purpose, five areas were selected: the first one in the Seine Bay (Haute-Normandie), the others along the Brittany and Basse-Normandie coasts. According to the results obtained within the French 
monitoring programme R.N.O., these areas are assumed to represent very opposite situations: on the one hand, the coasts of Brittany and Basse-Normandie which are very slightly contaminated by such man-made contaminants of industrial origin, on the other hand, the Seine Bay where the highest PCB levels are currently measured in mussels and other species living close to the Seine Estuary (Claisse et al., 1992; Lafite and Romaña, 2001; Abarnou et al., 2002) The second objective of this work was to look for any contamination differences related to species, to gender or to organs, all these factors being able to act either on the contamination levels or on the relative distribution of the PCB congeners. Finally, the health implications of these results were discussed first based upon M-PCBs, and secondly for DLPCBs using some simplifying assumptions.

\section{Experimental section}

\subsection{Sampling strategy}

The crustacean specimens were obtained from five areas along the coasts of Normandy and Brittany (Fig.1): Antifer, Granville, Roscoff, Le Conquet and Le Guilvinec.

Antifer (station 1), localised in the Seine Bay near an oil terminal, is greatly exposed to large contaminant discharges from the Seine River. The Seine River watershed represents about 78,600 $\mathrm{km}^{2}$ and regroups 30\% of the national population (Biger, 1996). Moreover, $40 \%$ of the French industrial activity is situated in this catchment area, as well as an important agricultural activity (Tessier, 2003). Conversely, Granville (station 2) and Roscoff (station 3) are characterised by agricultural activity and tourism in summer period; these areas are not influenced by large river discharges or industrial activity. Finally, the Iroise Sea, around Le Conquet (station 4), is situated in Western Brittany, influenced by important oceanic currents from Atlantic ocean and to some extent by local water exchanges with the Rade of Brest. Crustaceans were also obtained from Le Guilvinec (station 5), in Southern Brittany where professional fishing, notably of crustaceans, is of great economical concern.

The selection of the species depended on their availability at the sampling locations. Three crustacean species were chosen: the edible crab (Cancer pagurus), the spider crab (Maja brachydactyla), and the velvet swimming crab (Necora puber). They all represent an important part of the fished and consumed crustacean species in France. All crustaceans were obtained from local fishermen in February 2003. The characteristics of the studied samples are presented in Table 1 . Spider crabs were the only species obtained in each of the five sampling areas. 


\subsection{Sample preparation}

Preliminary sample pre-treatment steps were performed as soon as possible on receipt of the crustaceans. They included the determination of gender, the measurement of carapace length (between the union of the frontal spines and the posterior edge of the carapace) and total weight, and the dissection of each specimen to obtain muscle, hepatopancreas and gonads. As for velvet swimming crabs, each organ was analysed within pools that discriminated male and female specimens. All sample tissues were kept at $-20^{\circ} \mathrm{C}$ until freeze drying, and then the dry material was ground to obtain a fine homogeneous powder. The water content was estimated from the weight loss after freeze drying.

\subsection{Chemical analysis}

A precisely weighed amount of the powdered materiel, typically around one gram, was extracted in a hot Soxhlet extraction apparatus (Soxtec) during three hours with a hexane:acetone mixture (80:20). The solvent was carefully and completely evaporated. The residue was weighed to give the amount of extractible material and thus a crude estimation of the fat content. The extract was taken up by $5 \mathrm{ml}$ hexane. The lipids and co-extractible material were destroyed by adding one millilitre of concentrated sulphuric acid. After one night, the emulsion had separated, and the clear remanant hexane phase was taken up after decantation and centrifugation. This cleaned extract was further purified by adsorption chromatography on a Florisil column (Florisil, 60-100 mesh size, activated during one night at $200^{\circ} \mathrm{C}$, desactivated with $3 \%$ of demineralised water) eluted with pentane, PCBs, $p p$ '-DDE and HCB (Hexachlorobenzene) being all together in the same first elution fraction (volume 25 $\mathrm{ml}$ ). After evaporation of the solvent, the final extract was taken up by iso-octane, transferred into a chromatographic vial with addition of an internal standard (1,2,3,4tetrachloronaphtalene), and was then ready for the instrumental analysis. GC-ECD determination is carried out on a HP 5890 series II equipped with a CP-Sil19 column (60 m length, internal diameter $0.25 \mathrm{~mm}$, and $0.15 \mu \mathrm{m}$ phase film thickness) following optimised conditions described elsewhere (Jaouen-Madoulet et al., 2000).

Among PCBs, the seven indicator PCB congeners were measured (CB28, 52, 101, 118, 138, 153, 180), their sum being given as $\sum_{7}$ PCBs. However, the CB28 was always below the detection limit of $0.3 \mathrm{pg} . \mathrm{\mu l}^{-1}$. A few other congeners were also analysed to describe a larger range of chlorination from 3 to 8 chlorine molecules (CB105, 110, 128, 132, 149, 156, 170, $187,194)$ to check the appropriate resolution of the gas chromatography system, and because they can highlight underlying mechanisms acting on the distribution of organic contaminants 
in biota like bioaccumulation or biotransformation. The sum of all the 16 measured congener concentrations is referred below as $\sum_{16} \mathrm{PCBs}$.

\subsection{Quality control criteria}

The calibration of the system was performed within quite a large range using a multi-point (8) calibration curve to define the linearity range of our detector (ECD) for all contaminants, for example from 4 to $2000 \mathrm{pg} . \mathrm{\mu l}^{-1}$ for CB153. The relative precision of the method was checked for this type of samples by the analysis of six aliquots of a homogeneous tissue preparation of crustacean hepatopancreas. The results showed standard deviations less than 10 $\%$ for all congeners, which display a satisfactory reproducibility of the method. During the analysis of the real samples, analytical blanks were systematically measured every twelve samples. The blank were about $0.2 \mathrm{pg} . \mathrm{\mu l}^{-1}$, twenty times less than the concentrations of the lowest standard of CB153 (i.e., $<0.1$ ng.g $^{-1}$ ), and much less for other determinants. Finally, 6 replicates of a reference material, BCR-CRM349 (Cod Liver Oil) were analysed in order to determine the accuracy and precision of the method (Table 2). PCB recoveries varied between 77 and 115\%, except for CB105 which might interfere with a co-eluting compound. For HCB and pp'-DDE, recoveries were 88 and $120 \%$ respectively. The concentrations of the real samples were not corrected for recoveries. Moreover, the RSD values ranged from 3.8 to 19.6\%, with a mean of $9.7 \%$ for all PCBs. In the case of pesticides, the RSD was of 21 and $10 \%$ for HCB and $p p$ '-DDE respectively. All these results were in agreement with certified reference values and published complementary data (Schantz et al., 1993).

\subsection{Statistical treatment}

All data following a non-normal distribution according to the Shapiro-Wilk test ( $>00.05)$, a Mann Whitney U-test was used to compare contaminant concentrations and distributions between sampling areas, species and organs. All statistical tests were performed using Statistica Software 6.0.

\section{Results and discussion}

\subsection{Comparison of PCB concentrations and distribution between sampling sites}

Results of PCB contamination levels in crustacean hepatopancreas are reported on the dry weight (d.w.) basis (Table 3); water and lipid contents are also given to enable comparison with published data. Among the different crustaceans, the spider crab was the only species obtained in the five sites. 
The concentrations of $\sum_{16} \mathrm{PCBs}$ and CB153 congener in spider crab hepatopancreas showed significant inter-site differences (Mann-Whitney test, $\mathrm{p}<0.05$ ). The specimens from Antifer (M1) were the most contaminated, which confirms a chronic pollution of the whole Seine Bay mainly due to contaminant inputs by the Seine River (Lafite and Romaña, 2001; Abarnou et al., 2002). The $\sum_{16}$ PCB concentrations reached 2980 ng.g ${ }^{-1}$ d.w. (Table 3), about 6-, 10-, 30and 40-fold higher than those measured in the spider crabs from Le Conquet (M4), Le Guilvinec (M5), Roscoff (M3) and Granville (M2) respectively. For these two last areas, there is no significant riverine influence and no large urban and industrial wastes that could alter the water quality. Moreover, high tidal current contributes to the dilution of any terrestrial discharge by mixing into the general circulation (Salomon et al., 1988). These differences of PCB contamination levels in crustaceans from different areas are broadly speaking in agreement with those observed in mussels analysed in the French monitoring programme R.N.O. (Abarnou et al., 2002). The concentrations of CB153 were in the range of 200-500 ng. $\mathrm{g}^{-1} \mathrm{~d}$.w. in mussels from sites close to the Seine Estuary, whereas in the other areas, they varied from 5 to 50 ng.g ${ }^{-1}$ d.w., mussels from the Northern Brittany coast being the least contaminated. Unexpectedly, in spite of their origin from a presumed very clean area largely exposed to oceanic water circulation, the spider crabs collected around Le Conquet (M4: $\sum_{16} \mathrm{PCBs}=456$ ng.g ${ }^{-1}$ d.w.) presented slightly higher contamination than M3, M5 and M2 ( $\sum_{16} \mathrm{PCBs}=101,251,77$ ng.g ${ }^{-1} \mathrm{~d} . \mathrm{w}$, respectively) (Table 3). The spider crabs from Le Conquet have been fished near the outlet of the Rade of Brest. At ebb tide, this place might be influenced by contaminated water flowing from the Rade which is exposed to surrounding urban and industrial activities. Finally, PCB concentrations measured in the spider crabs from Southern Brittany (M5) were slightly higher than those of M2 and M3. Different studies have pointed out an influence of the plume of the River Loire panache until the sampling area (Lazure and Jegou, 1998), and higher PCB levels ([CB153]>100 ng.g ${ }^{-1}$ d.w.) have been observed in mussels collected at the Loire Estuary (Abarnou et al., 2002). Moreover, Le Guilvinec sampling area is characterised by muddy clay bottoms, which may promote the trapping of contaminants in superficial sediments and further their availability for benthic organisms.

Few studies have been carried out on the crustacean PCB contamination. The comparison of data is not straightforward because of the different modes of expression of the contamination (individual component concentrations or sum of different congeners; fresh weight basis, fat basis or dry mass basis), the type of tissues analysed or the whole specimen, and obviously 
the part of biological and environmental variability inherent to such measurements. For example, Kannan et al. (1998) found concentrations of CB153 in the range 540-1780 ng.g${ }^{1}$ w.w. in hepatopancreas of Callinectes sapidus from Georgia. Levels of this congener were 22 ng.g ${ }^{-1}$ w.w. in Palaemonetes antennarius collected from the River Arrone Italy (Bazzanti et al., 1997). Crangon crangon from the Southern Baltic Sea presented CB153 concentrations around 80 ng.g ${ }^{-1}$ lipids (Kannan et al., 1995). More recently, in the Belgian North Sea and the Western Scheldt Estuary, CB153 concentration range of 5.4-68 and 0.2-5.2 ng.g ${ }^{-1}$ w.w. were reported in the crab Lyocarcinus holsatus and the shrimp Crangon crangon respectively (Voorspoels et al., 2004). The concentration ranges measured in crustaceans from the French littoral (Table 3) are in good agreement with all these published data whichever the study area and species.

A comparison of the PCB patterns was carried out in the spider crab hepatopancreas from the five sampling sites (Fig. 2). For that purpose, the concentrations of each congener were normalised to that of CB153 which was the predominant component in all our samples. Similar profiles were observed whatever the geographical area with the predominance of six major congeners: CB153, 138, 180, 187, 118 and 170. Together, they represented 85-90\% of the $\sum_{16} \mathrm{PCBs}$, and CB153 contributed for $30-40 \%$ to this sum. These predominant congeners, except CB118, have 6-7 chlorine atoms by molecule and octanol-water coefficients corresponding to a maximum bioaccumulation tendency. Indeed, they are less hydrophobic than higher chlorinated ones (octa-, nona-, deca-PCBs), but are more readily bioavailable to organisms because they are not so tightly bound to sediment as the highest chlorinated PCBs (McFarland and Clarke, 1989). Moreover, the high proportions of these compounds in crustacean tissues reflect their low rates of biotransformation, and particularly the inability of these species to metabolise congeners with chlorine atoms in positions 2, 4, and 5 in one (CB118 and 138) or both rings (CB153 and 180). The persistence of these PCB congeners have been demonstrated in invertebrates and vertebrates (Bright et al., 1995; Kannan et al., 1995), and their proportions in marine species increased slightly with the trophic levels. Moreover, very lower relative abundance were observed in hepatopancreas of spider crabs for the $m, p$-unsubstituted PCBs (CB52, 101, 110, 132, 149). Different studies have pointed out the presence of cytochrome P-450 2B in crustacean tissues, which plays an important role in the biotransformation of xenobiotic compounds (Brown and John, 1992; Kannan et al., 1995; James and Boyle, 1998; Livingstone, 1998; Goerke and Weber, 2001). For PCBs, congeners with only $m, p$ vicinal H-atoms like CB52, 101 and 149 are metabolised by PB-type enzymes (cytochrome P-450 2B subfamily), whereas congeners with both $m, p$ and $o, m$ vicinal $\mathrm{H}$ - 
atoms, for example CB110 and 132, are metabolised by both cytochrome P-450 1A and cytochrome P-450 2B isozymes. Similar PCB fingerprints have been observed in other crustacean species (Duinker et al., 1983; Mothershead et al., 1991; Bright et al., 1995; Kannan et al., 1995; Menone et al., 2000; Miao et al., 2000;; Pruell et al., 2000).

\subsection{Comparison of pp'-DDE and HCB concentrations between sampling sites}

Though the use of $p p$ '-DDT has been prohibited for 25 years, $p p$ '-DDE is still measured in environmental samples. In spider crab hepatopancreas, levels varied between 2.2 and 24.7 ng. $g^{-1}$ d.w., whereas for HCB, they were at lower levels, between 0.33 and 0.83 ng.g ${ }^{-1} \mathrm{~d} . w$. (Table 3). Specimen from Antifer had the highest pp'-DDE concentrations (M1=24.7 ng.g${ }^{1}$ d.w.). However, as opposed to PCBs, the differences with the other sites were less important since spider crabs from Roscoff, Le Conquet and Le Guilvinec were less contaminated by a factor of five, and even ten times less for that from Granville. For HCB, in spider crabs from Antifer and Le Conquet, the concentrations were lower than in organisms from the other sites. Comparatively, Perugini et al. (2004) measured pp'-DDE concentrations varying from 77-676 ng. $g^{-1}$ lipid in the Norway lobster, Nephrops norvegicus, from the Central Adriatic Sea. In the White Sea Russia, pp'-DDE levels between 2.30-4.74 ng.g ${ }^{-1}$ w.w. were reported in the spider crab Hyas araneus (Muir et al., 2003). Finally, in the Belgian North Sea and the Western Scheldt Estuary, the crab Lyocarcinus holsatus and the shrimp Crangon crangon had pp'DDE concentrations between 1.3-11 ng.g ${ }^{-1}$ w.w. and $<0.81$ ng.g ${ }^{-1}$ W.w. respectively, whereas in these same specimens, HCB concentrations were 0.14-0.84 and 0.08-0.5 ng.g ${ }^{-1} \mathrm{w} . \mathrm{w}$. (Voorspoels et al., 2004). The concentration ranges measured in crustaceans from the French coastal waters are in the same range than all these published data whatever the study area and species (Table 3).

\subsection{PCB concentrations and distribution related to species, gender and organs}

\subsubsection{Comparison between crustacean species}

The contaminant levels and their distribution have been studied in different crustaceans species collected from Antifer (Table 3).

According to measurements in hepatopancreas, PCB concentrations were significantly greater in the spider crabs from Antifer than those in the edible crabs (Mann-Whitney test, $\mathrm{p}<0.05)$. Levels measured in the velvet swimming crabs from Antifer (Np1; CB153 = 594 ng. $\mathrm{g}^{-1} \mathrm{~d}$.w.) were between those measured in the spider crab $\left(\mathrm{M} 1\right.$; CB153 = 1271 ng.g $^{-1} \mathrm{~d} . \mathrm{w}$.) and in the edible crabs (C1; CB153 = 253 ng. $\mathrm{g}^{-1} \mathrm{~d} . \mathrm{w}$.). For HCB and pp'-DDE, concentrations 
measured in Necora puber (Np1) were higher than those of Maja brachydactyla (M1) and Cancer pagurus (C1). All individuals analysed in this study were male adult crustaceans. The differences of contaminant concentrations between species are probably due to differences in their life cycle (diet, moulting, migratory behaviour, metabolisation capacities). By far, food is the major route of organic contaminant accumulation for organisms, and this food contribution increases with trophic level. Decapod crustaceans have an omnivorous diet, consuming preferentially molluscs, small crustaceans and polychaetes (Cristo, 1998; Bernardez et al., 2000), but they also eat algae, echinoderms and fish carcasses. Moreover, velvet swimming crabs are sedentary species, oppositely to spider crabs and edible crabs. Necora puber are found all year long on intertidal rocky substrata in shallow waters $(<15 \mathrm{~m})$, whereas spider crabs and edible crabs spend winter in deep bottoms (between 40 and $100 \mathrm{~m}$ ), and migrate to shallow waters in summer for reproduction. Finally, moulting is a biological process specific to crustaceans; Cancer pagurus and Necora puber, as well as many other crustaceans, grow by successive moults throughout their life until about 20 years. The spider crab does not follow this general scheme as it moults and thus grows only during the first two years of its life. Some studies have suggested that contaminant elimination could happen during moulting (Swift, 1992; Raessler et al., 2005). Thus, all these particular behaviours of the three studied crustacean species can bring out differences on the bioavailability, uptake and elimination of organic contaminants.

A comparison of PCB patterns was carried out in the hepatopancreas of the crustaceans from Antifer (Fig. 3). Similar profiles were observed in all species with six predominant congeners, as previously shown for spider crabs: CB153, 138, 180, 187, 118 and 170. Together, they represented about the same contribution to the $\sum_{16} \mathrm{PCBs}, 90 \%$ for spider crabs and velvet swimming crabs, and $85 \%$ for edible crabs. However, the contribution of some compounds, including CB132, 138 and 149 appeared different between the three species (Mann-Whitney test, $\mathrm{p}<0.05$ ). In spider crabs, CB149 and 132 represented about $0.8 \%$ and $0.4 \%$ of the sum of PCBs, so approximately 2 -fold lower than in edible crab tissues $(1.6 \%$ and $0.8 \%$ respectively). As related before, decapod crustaceans are able to partially biotransform some PCBs resulting from cytochrome P-450 2B isozyme activity. However, some studies have also pointed out variable metabolic efficiencies among the crustacean species (Brown and John, 1992; James and Boyle, 1998; Goerke and Weber, 2001). Our results highlighted higher metabolic capacities for Maja brachydactyla than the two other crustaceans. Moreover, the CB138/CB153 ratio depended on the species, since it was around $0.35-0.45$ in spider crabs and 0.70-0.95 in edible crabs and velvet swimming crabs. The CB138 congener is 
characteristic of river influence and related to the suspended matter due to its physicochemical properties (Marchand et al., 1990). The higher contribution of this congener in male adult specimens of Necora puber and Cancer pagurus reflected their sedentary behaviour (Latrouite and Le Foll 1989), and suggested that they are more representative of the PCB contamination of the studied area than the adult male spider crabs.

\subsubsection{Effect of gender}

With the aim to characterise a possible influence of gender, a comparison of the PCB levels and distribution was performed in crustaceans collected from Antifer. Female edible crabs had hepatic PCB concentrations (both $\mathrm{CB} 153$ and $\sum_{16} \mathrm{PCBs}$ ) significantly greater than male individuals (Mann-Whitney test, $\mathrm{p}<0.05$ ), whereas no sex differences were observed for spider crabs. For HCB and pp'-DDE, the highest levels were measured in male spider crabs (Mann-Whitney test, $\mathrm{p}<0.05$ ). The effect of gender in the distribution of individual PCB congeners was also examined. No significant differences were observed for Cancer pagurus and Necora puber, whereas CB118 was significantly higher in male spider crabs (8 and 1\% of the $\sum_{16} \mathrm{PCBs}$ for male and female respectively) (Mann-Whitney test, $\mathrm{p}<0.05$ ).

\subsubsection{Comparison between organs}

The physiological functions might act on the distribution of contaminants mainly related to the reproduction status, the metabolic activity or the lipid content in specific organs. The contaminant levels and distribution in different tissues (hepatopancreas, muscle and gonads) have been studied in more details in female crustaceans collected from Antifer and Granville, the most and the least contaminated areas respectively (Table 4).

In all cases, hepatopancreas had the highest PCB, pp'-DDE and HCB concentrations, followed by gonads and muscle (Mann-Whitney test, $\mathrm{p}<0.05$ ). These results were in agreement with the lipid content measured in each organ $(40-60 \%, 10-20 \%$ and $1-3 \%$ for hepatopancreas, gonads and muscle respectively); similar observations are usually made when examining the distribution of persistent hydrophobic compounds in biological tissues. The ratios of CB153 concentration in crustacean hepatopancreas to that in muscle were 56:1 and 36:1 for spider crabs and edible crabs respectively. At Granville, systematically lower hepatopancreas:muscle ratios were obtained, 43:1 and 12:1 respectively. The important PCB levels in biota and in sediment from the Seine Bay (Abarnou et al., 1987; Loizeau and Abarnou, 1994; Goerke and Weber, 2001; Johansson et al., 2004; Munschy et al., 2004), in addition to the strong capacity to accumulate these contaminants in hepatopancreas can 
explain such differences between samples from the two sites. Similar results were obtained for the PCB distribution between hepatopancreas and gonads.

A non-parametric Mann-Whitney test $(\mathrm{p}<0.05)$ enabled us to highlight significant differences in the distribution of individual PCB congeners among organs. As well in Antifer as in Granville, both for spider crabs and for edible crabs, significant lower contributions of the congeners CB52, 132 and 149 were measured in hepatopancreas compared to that in muscle, confirming that the hepatopancreas is the major site of cytochrome P450-dependent biotransformation of PCBs in crustaceans (James and Boyle, 1998; Livingstone, 1998).

One of the aims of this work was to look for any contamination difference related to species, to gender or to organs on the PCB concentrations and distribution in crustaceans. Our results showed that the major variation factor is the type of tissues, in relation with its lipid content. Moreover, some differences were observed in the three crustacean species both for the PCB levels and their distribution. The crustacean life cycle, mainly the diet, the moulting, the migratory behaviour, as well as their different metabolic capacities can explain such results. Finally, gender had very slight effects on the PCB concentrations and distribution. However, in this study, all specimens were sampled in winter period (February), when the female crustaceans are still in period of sexual rest. Complementary studies should be carried out in summer, during the spawning period, to observe a possible difference between males and females.

\subsection{PCB contamination and health implications}

Depending on their substitution pattern, the PCB components exhibit different toxicity mechanisms, either a dioxin like or a non-dioxin like toxicity type.

Some congeners with two or more chlorine atoms at the ortho positions, the marker congeners (M-PCBs), express a non dioxin-like mechanism; they act on the central nervous system, the thyroid and the endocrine system, but only after a relatively high incidental intake or after continuous accumulation by long-term intake (ATSDR, 2000). Presently, in spite of their high levels in environmental samples and their toxicity, there is a lack of international regulations on the safe limits of M-PCBs in food. In 2002, the World Health Organisation established a maximum total daily intake for those compounds TDI (M-PCBs) of $0.02 \mu \mathrm{g} . \mathrm{kg}^{-1}$ body weight per day, PCB concentration being expressed in Aroclor 1254 equivalent (AFSSA, 2003). This TDI was derived from a long-term toxicity experiment on monkey, on the basis of neurobehavioral and immunological effects. By considering that in food and 
especially in sea products the 7 indicator PCBs (CB28, 52, 101, 118, 138, 153, 180) represent all together approximately more than half of the PCB concentration expressed in Aroclor 1254 equivalent (or technical mixture of the same chlorination degree), the PCB exposure should be less than $0.01 \mu \mathrm{g} / \mathrm{kg}$ b.w. expressed as the sum of the concentrations of indicator congeners $\left(\Sigma_{7} \mathrm{PCBs}\right)$ (AFSSA, 2003). Back to our data, taking into account average concentrations in the different organs from crustaceans and considering a body weight mean of $65 \mathrm{~kg}$, it becomes easy to estimate the maximum amount of crustacean meat that could be eaten before reaching the safety limit. Looking to organisms from Antifer, the orders of magnitude were around 70-120 g for crustacean muscle, whereas, for other consumable tissues, amounts became much smaller, 3-10 g for gonads and 1-2 g for hepatopancreas. As far as the lowest contaminated crustaceans from Granville are concerned, consumable quantities are 30, 20 and 40 times higher in hepatopancreas, muscle and gonads respectively. According to AFSSA (2003), French consume $5 \mathrm{~g}$ of crustaceans and molluscs on average per person and per day, to which mussels contribute for the main part. It signifies that globally the consumption of crustaceans is safe, except that of hepatopancreas and gonads of specimens from Antifer that could present a risk for human health.

Oppositely to the indicator PCBs, some congeners which have no or only one chlorine atom at the ortho-position, present the same toxicity mechanisms as 2,3,7,8-TCDD and other 2,3,7,8-substituted PCDD/Fs. These dioxin-like PCBs (DL-PCBs) provoke immuno- and reproductive toxicity, they negatively influence the organism growth and the development of the central nervous system, and they have carcinogenic potency. However, the effects become only manifest above a defined critical body burden (JECFA, 2002). For these reasons, food safety agencies have recently taken the DL-PCBs into account. The EU Directive has established a maximum limit for both groups of contaminants, dioxins and DL-PCBs. For fish and sea food products, the maximum limit is fixed at 4 pg TEQ.g ${ }^{-1}$ w.w., whereas a warning limit is set at 3 pg TEQ.g ${ }^{-1}$ w.w., above which complementary investigations are required to explain and reduce such high levels. This regulation should have come into force since December 2004 (Gallani et al., 2004) but is still under discussion due to the lack of data on DL-PCBs. In a previous study on the contamination of crustaceans (Bodin et al., 2004), preliminary results on dioxins and PCBs (indicators and dioxin-like compounds) were obtained on a limited set of pooled samples from different sites along the French coasts. Contribution of DL-PCBs to the total TEQ was about 50-60\% in all samples. Interestingly, CB118 belongs to the group of indicator PCBs and consequently it was measured in the present study, as well as two other mono-ortho PCBs, CB105 and 156. Based on their 
composition in crustaceans obtained in Bodin et al. (2004), and because, as shown earlier, PCB composition does not vary to a large extent within similar organisms from a same taxon and within tissues, the composition of one congener or of a specified group of congeners may be used to estimate the total PCB composition or the TEQ (DL-PCBs). This remains true in the case of chronic contamination, when there is no local source of PCB contamination with specified unusual composition. Practically, individual TEQs for CB105, 118 and 156 were calculated from their measured concentrations and from their respective TEFs (Van den Berg et al., 1998). According to previous results (Bodin et al., 2004), these compounds contribute approximately for $10-30 \%$ to the TEQ (DL-PCBs). By multiplying the measured TEQ (CB105, 105, 118) by a conversion factor, an estimated TEQ (DL-PCBs) was obtained. This conversion factor was here fixed at 10 to account for an approximate $10 \%$ composition of these three congeners, which leads to an over-estimated TEQ (DL-PCBs), and consequently to a safer situation in view of its application for health protection. The estimated TEQ (DLPCBs) were very different among the various organs (Fig. 4). Most consumers eat the crustacean muscle only; in this case, the estimated TEQ (DL-PCBs) are far below the regulatory limits, whatever the species or their geographical origin. However, some people also appreciate to eat hepatopancreas and gonads. Only the gonads of crustaceans from Antifer were above the maximum limit of 4 pg TEQ.g ${ }^{-1}$ W.W., whereas considering hepatopancreas, specimens from Antifer, Le Conquet and spider crabs from Le Guilvinec were unfit for human consumption, without considering the consumed amount. The recent EU regulation (JECFA, 2002) on the maximum intake was set at 70 pg TEQ.kg-1 b.w. per month, or an average daily intake of 2.33 pg TEQ. $\mathrm{kg}^{-1} \mathrm{~b} . \mathrm{w}$. Using a same approach as earlier on MPCBs, it becomes possible to estimate and compare maximum quantities of hepatopancreas, muscle and gonads that may be eaten safely. This approach, based on TEQ estimation, lead to consumable quantities which were very close to that obtained by the first estimation for $\mathrm{M}$ PCBs.

The directives on food safety we used rely upon very different hypotheses, the first one on M- PCBs and the second one on DL-PCBs. It was completely out of our objectives to discuss the basic knowledge leading to these regulations. We only aimed at comparing concentrations in various crustacean samples to these safety levels. Whichever the approach, very similar results were obtained. They pointed out differences of crustacean tissue contamination and could modify consumption habits, especially in the case of regular consumers. Moreover, based on concentrations, the TEQ (DL-PCBs) approach was much more restricting than the TDI approach, as it excluded more contaminated samples, especially hepatopancreas and 
gonads in crustaceans from the most contaminated areas. The estimation of the TEQ (DLPCBs) is based on the analysis of very few DL-PCBs and on the use of a conversion factor voluntary over-estimated to protect the consumer's health. We are aware of the fact that this simplifying approach should be further investigated. The generalisation of such a conversion factor, to transform PCB data in TEQ data, requires more information on the exact composition of all the DL-PCBs in food. Some among the congeners, particularly CB126, contributes in a significant way to the TEQ because of their high TEF. However, their concentrations in crustaceans are very low, which complicates their measurement. The use of marker PCBs or a few other easily measured congeners could be a simplified method. They could first be used for screening purpose in food quality control, and secondly, in case of results above a defined limit, let say about 2-3 pg “over-estimated” TEQ.g ${ }^{-1}$, the appropriate analytical protocol should be used for confirmation. This proposed approach might be compared to bioanalytical methods like CALUX assay and US EPA method 4425. Both methods consist in rapid and inexpensive assay. If the CALUX method provides direct information on the TEQ the proposed simplified chemical approach is based on the analysis of M-PCBs and a few mono-ortho PCB congeners and avoids the use of more sophisticated and expensive analytical technique. This confirmation method (HRGC-HRMS) should be used when the calculated approximate values fall close to the safety limits. However, the applicability and interest of such a screening method relies on the validity of the conversion factors and consequently the exact composition of PCBs. This last aspect should be more thoroughly investigated based on a larger data set, including data on very different species from various origins.

\section{Acknowledgments}

This work was partially funded by the Regional Council of Brittany. Moreover, we would like to thank fishermen who very kindly offered their help when sampling the crustaceans. We also would like to express our gratitude to Dr. Guillou (IUEM, Plouzané) and Dr. Latrouite (IFREMER, Plouzané) for their advices on the biological aspects of this work and their support all along the study.

\section{References}

Abarnou, A., Avoine, J., Dupont, J.P., Lafite, R., Simon, S., 1987. Role of suspended sediments on the distribution of PCB in the Seine Estuary France. Cont. Shelf Res. 7, 13451350. 
Abarnou, A., Loizeau, V., Le Guellec, A-M., Jaouen-Madoulet, A., 2002. Contaminants in marine foodwebs. Revue Méd. Vét. 153, 425-432.

AFSSA, 2000. Dioxines: données de contamination et d'exposition de la population française. Conseil Supérieur d'Hygiène Publique de France section Aliments et Nutrition, France.

AFSSA, 2003. Avis de l'Agence française de sécurité sanitaire des aliments sur l'existence éventuelle d'une corrélation significative entre les teneurs dans les différents congénères de PCB. Conseil Supérieur d'Hygiène Publique de France section Aliments et Nutrition. Saisine n²002-SA-0149, France.

Ahlborg, U.G., Becking, G.C., Birnbaum, L.S., Brouwer, A., Derks, H.J.G.M., Feeley, M., Golor, G., Hanberg, A., Larsen, J.C., Liem, A.K.D., 1994. Toxic equivalency factors for dioxin-like PCBs: Report on WHO-ECEH and IPCS consultation, December 1993. Chemosphere 28, 1049-1067.

ATSDR, 2000. Toxicological profile for polychlorinated biphenyls Update. Agency for Toxic Substances and Disease Registry, US Public Health Service, Atlanta, GA, USA

Baars, A.J., Bakker, M.I., Baumann, R.A., Boon, P.E., Freijer, J.I., Hoogenboom, L.A.P., Hoogerbrugge, R., van Klaveren, J.D., Liem, A.K.D., Traag, W.A., de Vries, J., 2004. Dioxins, dioxin-like PCBs and non-dioxin-like PCBs in foodstuffs occurrence and dietary intake in the Netherlands. Toxicol. Lett. 151, 51-61.

Bazzanti, M., Chiavarini, S., Cremisini, C., Soldati, P., 1997. Distribution of PCB congeners in aquatic ecosystems: A case study. Environ. Int. 236, 799-813.

Beliaeff, B., Smith, P.J., 1996. Estimation of coastal water contamination long term trend using seasonal linear models. Wat. Resour. Bull. 32, 595-603.

Bernardez, C., Freire, J., Gonzalez-Gurriaran, E., 2000. Feeding of the spider crab Maja squinado in rocky subtidal areas of the Ría de Arousa north-west Spain. J. Mar. Biol. Ass. U.K. 80, 95-102.

Biger, E., 1996. Mesure du bruit de fond géochimique naturel et mise en évidence de l'influence anthropique en zone rurale: application au bassin de la Seine. Master Degree Report, Université Pierre et Marie Curie, Paris VI, France.

Bodin, N., Abarnou, A., Defour, S., Fraisse, D., 2004. PCBs, PCDD/Fs and PBDEs in crustaceans from different French coastal sites. Organohalogen Compounds 66, 1733-1738.

Bordajandi, R.L., Gomez, G., Abad, E., Rivera, J., del Mar Fernandez-Baston, M., Blasco, J., Gonzalez, M.J., 2004. Survey of persistent organochlorine contaminants PCBs, PCDD/Fs and HAPs, heavy metals $\mathrm{Cu}, \mathrm{Cd}, \mathrm{Zn}, \mathrm{Pb}$ and $\mathrm{Hg}$, Arsenic in food samples from Huelva Spain: Levels and health implications. J. Agric. Food Chem. 52, 992-1001.

Bright, D.A., Dushenko, W.T., Grundy, S.L., Reimer, K.J., 1995. Effects of local and distant contaminant sources: polychlorinated biphenyls and other organochlorines in bottomdwelling animals from an Arctic estuary. Sci. Total Environ. 160/161, 265-283.

Brown, J., John, F., 1992. Metabolic alterations of PCB residues in aquatic fauna: distributions of cytochrome P4501A- and P4502B-like activities. Mar. Environ. Res. 34, 261266.

Claisse, D., 1989. Chemical concentrations of French coasts: the result of a ten year mussel watch. Mar. Pollut. Bull. 20, 523-528.

Claisse, D., Joanny, M., Quintin, J.Y., 1992. Le Réseau National d'Observation de la qualité du milieu marin (RNO). Analusis 20, 19-22.

Connolly, J.P., 1991. Application of a food chain model to polychlorinated biphenyl contamination of the lobster and winter flounder food chains in New Bedford Harbor. Environ. Sci. Technol. 25, 760-770.

Cristo, M., 1998. Feeding ecology of Nephrops norvegicus Decapoda: Nephropidae. J. Nat. Hist. 32, 1493-1498. 
Duinker, J.C., Hillebrand, M.T.J., Boon, J.P., 1983. Organochlorines in benthic invertebrated and sediments from the Dutch Wadden Sea; identification of individual components. Neth. J. Sea Res. 17, 19-38.

Focant, J-F., Eppe, G., Pirard, C., Massart, A-C., Andre, J-E., De Pauw, E., 2002. Levels and congener distributions of PCDDs, PCDFs and non-ortho PCBs in Belgian foodstuffs: Assessment of dietary intake. Chemosphere 482, 167-179.

Gallani, B., Verstraete, F., Boix, A., Von Holst, C., Anklam, E., 2004. Levels of dioxins and dioxin-like PCBs in food and feed in Europe. Organohalogen Compounds 66, 1917-1924.

Goerke, H., Weber, K., 2001. Species-specific elimination of polychlorinated biphenyls in estuarine animals and its impact on residue patterns. Mar. Environ. Res. 512, 131-149.

James, M.O., Boyle, S.M., 1998. Cytochromes P450 in crustacea. Comp. Biochem. Physiol. C $121,157-172$.

Jaouen-Madoulet, A., Abarnou, A., Le Guellec, A-M., Loizeau, V., Leboulenger, F., 2000. Validation of an analytical procedure for polychlorinated biphenyls, coplanar polychlorinated biphenyls and polycyclic aromatic hydrocarbons in environmental samples. J. Chromatogr. A 886, 153-173.

JECFA, 2002. Polychlorinated dibenzodioxins, polychlorinated dibenzofurans, and coplanar polychlorinated biphenyls. In: Canady, R., Crump, K., Feeley, M., Freijer, J., Kogevinas, M., Malisch, R., Verger, P., Wilson, J., Zeilmaker, M. (eds), Safety Evaluation of Certain Food Additives and Contaminants. Report of the 57th Meeting of the Joint FAO/WHO Expert Commitee on Food Additives and Contaminants. WHO Fodd Additives Series, vol. 48, World Health Organisation, Geneva, pp. 451-664.

Jensen, S., 1966. Report of a new chemical hazard. New Sci. 32, 62.

Johansson, I., Moisan, K., Guiot, N., Truquet, I., Munschy, C., Tronczynski, Y., 2004. Levels and trends of organohalogen compounds in mussels from the Seine estuary in 19812003. Organohalogen Compounds 66, 1868-1876.

Kannan, N., Reusch, T.B.H., Schulz-Bull, D.E., Petrick, G., Duinker, J.C., 1995. Chlorobiphenyls: Model compounds for metabolism in food chain organisms and their potential use as ecotoxicological stress indicators by application of the metabolic slope concept. Environ. Sci. Technol. 29, 1851-1859.

Kannan, K., Nakata, H., Stafford, R., Masson, G.R., Giesy, J.P., 1998. Bioaccumulation and toxic potential of extremely hydrophobic polychlorinated biphenyl congeners in biota collected at a superfund site contaminated with Arochlor 1268. Environ. Sci. Technol. 32, 1214-1221.

Lafite, R., Romaña, L-A., 2001. A Man-altered microtidal estuary: the Seine Estuary France, introduction to special issue. Estuaries 24, 939.

Lazure, P., Jegou, A-M., 1998. 3D modelling of seasonal evolution of Loire and Gironde plumes on Biscay Bay continental shelf. Oceanol. Acta 212, 165-177.

Livingstone, D.R., 1998. The fate of organic xenobiotics in aquatic ecosystems: quantitative and qualitative differences in biotransformation by invertebrates and fish. Comp. Biochem. Physiol. A 120, 43-49.

Loizeau, V., Abarnou, A., 1994. Distribution of Polychlorinated biphenyls in dab Limanda limanda from the baie de seine Eastern Channel. Mar. Environ. Res. 382, 77-91.

Loizeau, V., Abarnou, A., Cugier, P., Jaouen-Madoulet, A., Le Guellec, A-M., Menesguen, A., 2001. A Model of PCB Bioaccumulation in the Sea Bass Food Web from the Seine Estuary Eastern English Channel. Mar. Pollut. Bull. 43, 242-255.

Mackay, D., Fraser, A., 2000. Bioaccumulation of persistent organic chemicals: mechanisms and models. Environ. Pollut. 110, 375-391. 
Marchand, M., Abarnou, A., Marcaillou-Lebaut, C., 1990. Les Polyclorobiphényles (PCB) en milieu marin. Biogéochimie et écotoxicologie. Rapports scientifiques et techniques de l'Ifremer $n^{\circ} 18$.

McFarland, V.A., Clarke, J.U., 1989. Environmental occurrence, abundance and potential toxicity of polychlorinated biphenyl congeners: considerations for a congeners-specific analysis. Environ. Health Perspect. 91, 225-231.

Menone, M.L., Bortolus, A., Botto, F., Aizpun de Moreno, J.E., Moreno, V.J., Iribarne, O., Metcalfe, T.L., Metcalfe, C.D., 2000. Organochlorine contaminants in a coastal lagoon in Argentine: Analysis of sediment, crabs, and cordgrass from two different habitats. Estuaries 23, 583-592.

Miao, X-S., Swenson, C., Woodward, L.A., Li, Q.X., 2000. Distribution of polychlorinated biphenyls in marine species from French Frigate Shoals, North Pacific Ocean. Sci. Total Environ. 257, 17-28.

Mothershead, R., Hale, R.C., Greaves, J., 1991. Xenobiotic compounds in blue crabs from a highly contaminated urban subestuary. Environ. Toxicol. Chem. 10, 1341-1349.

Muir, D., Savinova, T., Savinov, V., Alexeeva, L., Potelov, V., Svetochev, V. 2003. Bioaccumulation of PCBs and chlorinated pesticides in seals, fishes and invertebrates from the White Sea, Russia. Sci. Total Environ. 306, 111-131.

Munschy, C., Moisan, K., Tronczynski, Y. 2004. Levels and patterns of PCBs and PCDD/Fs in different tissues of the marine flatfish dab Limanda limanda from the English Channel, France. Organohalogen Compounds 66, 1695-1703.

O’Connor, T.P., 2004. Trends in chemical concentrations in mussels and oysters collected along the US coasts from 1986 to 1993. Mar. Environ. Res. 41, 183-200

Perugini, M., Cavaliere, M., Giammarino, A., Mazzone, P., Olivieri, V., Amorena, M. 2004. Levels of polychlorinated biphenyls and organochlorine pesticides in some edible marine organisms from the Central Adriatic Sea. Chemosphere 575, 391-400.

Pruell, R.J., Taplin, B.K., McGovern, D.G., McKinney, R., Norton, S.B. 2000. Organic contaminant distributions in sediments, polychaetes Nereis virens and American lobster Homarus americanus from a laboratory food chain experiment. Mar. Environ. Res. 49, 19-36.

Raessler, M., Rothe, J., Hilke, I. 2005. Accurate determination of $\mathrm{Cd}$, $\mathrm{Cr}$, $\mathrm{Cu}$ and $\mathrm{Ni}$ in woodlice and their skins--is moulting a means of detoxification? Sci. Total Environ. 337, 8390.

Salomon, J.C., Guéguéniat, P., Orbi, A., Baron, Y., 1988. A lagrangian model for long term tidally induced transport and mixing. Verification by artificial radionucleide concentrations. In: J.C. Guary, P. Guéguéniat, R.J. Pentreath (eds), Radionucleides: a Tool for Oceanography. Elsiever, Amsterdam.

Schantz, M.M., Parris, R.M., Kurz, J., Ballschmiter, K., Wise, S.A. 1993. Comparison of methods for the gas-chromatographic determination of PCB congeners and chlorinated pesticides in marine reference materials. Fresenius J. Anal. Chem. 346, 766-778.

Smith, A.G., Gangolli, S.D. 2002. Organochlorine chemicals in seafood: occurrence and health concerns. Food Chem. Toxicol. 40, 767-779.

Swift, D.J. 1992. The accumulation of plutonium by the European lobster Homarus gammarus L. J. Environ. Radioactiv. 161, 1-24.

Tessier, L. 2003. Transport et caractérisation des matières en suspension dans le bassin versant de la Seine: identification de signatures naturelles anthropiques. Ph.D. Thesis, Ecole Nationale des Ponts et Chaussée, Paris, France.

Van den Berg M., Birnbaum L., Bosveld A.T.C., Brunström B., Cook P., Feeley M., Giesy J.P., Hanberg A., Hasegawa R., Kennedy S.W., Kubiak T., Larsen J.C., van Leeuwen F.X.R., Liem A.K.D., Nolt C., Peterson R.E., Poellinger L., Safe S., Schrenk D., Tillitt D., Tysklind 
M., Younes M., Fredrik Wærn F., and Zacharewski T. 1998. Toxic equivalents factors TEF for PCBs, PCDDs, PCDFs for humans and wildlife. Environ. Health Perspect. 106, 775-792.

Voorspoels, S., Covaci, A., Maervoet, J., De Meester, I., Schepens, P. 2004. Levels and profiles of PCBs and OCPs in marine benthic species from the Belgian North Sea and the Western Scheldt Estuary. Mar. Pollut. Bull. 49, 393-404. 


\section{Table and figure list}

Table 1. Biological characteristics of the sampled species. For Necora puber, a first pool of 11 males, and a second of 10 females were analysed.

Table 2. Measured concentrations and recoveries of PCBs and pesticides in CRM349.

Table 3. Organochlorinated contaminants in the hepatopancreas of male crustaceans from French coastal sites: mean concentrations of CB153 (ng.g $\left.{ }^{-1} \mathrm{~d} . w.\right)$, sum of the 16 analysed PCBs (ng.g ${ }^{-1}$ d.w.), sum of the 7 indicator PCBs (ng.g ${ }^{-1}$ d.w.), pp'-DDE (ng. ${ }^{-1}$ d.w.) and HCB (ng. $g^{-1}$ d.w.). Lipid content (\%) is expressed on a dry weight basis.

Table 4. Organochlorinated contaminants in different organs (hepatopancreas, muscle, gonads) of female crustaceans collected at Antifer (A) and Granville (B): mean concentrations of CB153 (ng.g ${ }^{-1}$ d.w.), sum of the 16 analysed PCBs (ng.g ${ }^{-1}$ d.w.), sum of the 7 indicator PCBs (ng.g ${ }^{-1}$ d.w.), pp'-DDE (ng.g ${ }^{-1}$ d.w.) and HCB (ng.g ${ }^{-1}$ d.w.). Lipid content (\%) is expressed on a dry weight basis.

Fig. 43. Map of the studied areas. $\mathrm{M}=$ Maja brachydactyla; $\mathrm{C}=$ Cancer pagurus; $\mathrm{Np}=$ Necora puber.

Fig. 44. PCB average pattern in hepatopancreas of male spider crabs from the five sampling sites (Antifer, Granville, Roscoff, Le Conquet and Le Guilvinec). Concentrations of each congener were normalised to CB153 $(100 \times \mathrm{CBx} / \mathrm{CB} 153)$. Error bars show the range (minimum and maximum) of relative concentrations among the five sampling sites.

Fig. 45. PCB average patterns in hepatopancreas of male crustaceans from Antifer $(\mathrm{M}=$ Maja brachydactyla; $\mathrm{C}=$ Cancer pagurus; $\mathrm{Np}=$ Necora puber $)$. Concentrations of each congener were normalised to $\mathrm{CB} 153(100 \times \mathrm{CBx} / \mathrm{CB} 153)$. Error bars show the range (minimum and maximum) of relative concentrations for each species.

Fig. 46. Estimated TEQ (DL-PCBs) concentrations in organs $(\mathrm{H}=$ hepatopancreas; $\mathrm{M}=$ muscle; $\mathrm{G}=$ gonads) of various crustacean species $(\mathrm{M}=$ Maja brachydactyla; $\mathrm{C}=$ Cancer pagurus; $\mathrm{Np}=$ Necora puber) from different coastal areas (1-5; see map Fig.1) 
Table 3. Biological characteristics of the sampled species. For Necora puber, a first pool of 11 males, and a second of 10 females were analysed.

\begin{tabular}{|c|c|c|c|c|c|c|c|c|c|}
\hline \multirow{2}{*}{ Sites } & \multirow{2}{*}{ Species name } & \multirow{2}{*}{ Common name } & \multirow{2}{*}{ Abbreviation } & \multicolumn{2}{|c|}{$\mathrm{N}$} & \multicolumn{2}{|c|}{ Weight (g) } & \multicolumn{2}{|c|}{ Lenght $(\mathrm{cm})$} \\
\hline & & & & $\mathrm{m}$ & $\mathrm{f}$ & $\mathrm{m}$ & $\mathrm{f}$ & $\mathrm{m}$ & $\mathrm{f}$ \\
\hline \multirow[t]{3}{*}{ Antifer } & Maja brachydactyla & spider crab & M1 & 4 & 4 & $560 \pm 192$ & $491 \pm 118$ & $115 \pm 1.8$ & $11.6 \pm 0.5$ \\
\hline & Cancer pagurus & edible crab & $\mathrm{C} 1$ & 3 & 3 & $463 \pm 193$ & $432 \pm 121$ & $13.8 \pm 2.4$ & $14.7 \pm 1.5$ \\
\hline & Necora puber & velvet swimming crab & Np1 & pool (10) & pool (10) & $89 \pm 15$ & $85 \pm 8$ & $4.9 \pm 0.3$ & $4.9 \pm 0.3$ \\
\hline \multirow[t]{2}{*}{ Granville } & Maja brachydactyla & spider crab & M2 & 3 & 3 & $1177 \pm 185$ & $799 \pm 70$ & $15 \pm 1$ & $14.5 \pm 0.1$ \\
\hline & Cancer pagurus & edible crab & $\mathrm{C} 2$ & 3 & 3 & $543 \pm 31$ & $511 \pm 48$ & $15 \pm 0.5$ & $15 \pm 0.5$ \\
\hline Roscoff & Maja brachydactyla & spider crab & M3 & 3 & 3 & $1089 \pm 135$ & $756 \pm 59$ & $14.3 \pm 0.6$ & $13.8 \pm 0.3$ \\
\hline \multirow[t]{2}{*}{ Le Conquet } & Maja brachydactyla & spider crab & M4 & 5 & 5 & $1684 \pm 261$ & $802 \pm 115$ & $17 \pm 1.4$ & $13.9 \pm 0.9$ \\
\hline & Cancer pagurus & edible crab & $\mathrm{C} 4$ & 5 & 5 & $920 \pm 129$ & $926 \pm 118$ & $17 \pm 0.9$ & $19.5 \pm 1.1$ \\
\hline \multirow[t]{2}{*}{ Le Guilvinec } & Maja brachydactyla & spider crab & M5 & 3 & 3 & $680 \pm 132$ & $702 \pm 80$ & $13.2 \pm 0.8$ & $13.7 \pm 0.3$ \\
\hline & Cancer pagurus & edible crab & C5 & 3 & 3 & $1002 \pm 159$ & $775 \pm 38$ & $17.3 \pm 0.3$ & $17.5 \pm 0.7$ \\
\hline
\end{tabular}



Table 4. Measured concentrations and recoveries of PCBs and pesticides in CRM349.

\begin{tabular}{|c|c|c|c|c|c|c|c|}
\hline & $\begin{array}{c}\text { Certfied } \\
\text { values } \\
\left.\left(\mathrm{ng}^{-1}\right)^{-1}\right) \\
\end{array}$ & $\begin{array}{c}\mathrm{SD}^{\mathrm{a}} \\
\left.\text { (ng. } \mathrm{g}^{-1}\right) \\
\end{array}$ & $\begin{array}{l}\mathrm{RSD}^{\mathrm{b}} \\
(\%) \\
\end{array}$ & $\begin{array}{c}\text { Experimental } \\
\text { mean }(\mathrm{n}=6) \\
\left(\mathrm{ng} \cdot \mathrm{g}^{-1}\right)\end{array}$ & $\begin{array}{c}\mathrm{SD}^{\mathrm{c}} \\
\text { (ng. } \mathrm{g}^{-1} \text { ) } \\
\end{array}$ & $\begin{array}{r}\mathrm{RSD}^{\mathrm{d}} \\
(\%) \\
\end{array}$ & $\begin{array}{c}\text { Recovery } \\
\text { (\%) }\end{array}$ \\
\hline \multicolumn{8}{|l|}{$P C B$} \\
\hline CB28 & 68 & 7 & 10.3 & 54.6 & 10.1 & 18.5 & 80.3 \\
\hline CB52 & 149 & 20 & 13.4 & 116.0 & 16.4 & 14.2 & 77.8 \\
\hline CB101 & 370 & 17 & 4.6 & 300.5 & 13.5 & 4.5 & 81.2 \\
\hline CB110 & $175^{f}$ & & & 157.6 & 18.9 & 12.0 & 87.6 \\
\hline CB149 & $284^{f}$ & 55 & 19.4 & 228.0 & 12.5 & 6.0 & 80.3 \\
\hline CB118 & 454 & 31 & 6.8 & 412.9 & 15.5 & 3.8 & 91.0 \\
\hline CB153 & 938 & 49 & 5.2 & 990.7 & 66.5 & 6.7 & 105.6 \\
\hline CB132 & & & & 65.5 & 11.2 & 17.1 & \\
\hline CB105 & $51^{\mathrm{f}}$ & & & 109.3 & 21.2 & 19.4 & 218.6 \\
\hline CB138 & $765^{f}$ & 74 & 9.7 & 881.9 & 52.5 & 6.0 & 115.3 \\
\hline CB187 & $276^{f}$ & 14 & 5.1 & 222.9 & 12.5 & 5.6 & 80.8 \\
\hline CB128 & $104^{f}$ & 9 & 8.7 & 90.2 & 8.0 & 8.8 & 86.8 \\
\hline CB156 & $40^{\mathrm{f}}$ & & & 39.0 & 6.3 & 16.2 & 97.6 \\
\hline CB180 & 280 & 22 & 7.9 & 243.5 & 13.3 & 5.5 & 87.0 \\
\hline CB170 & $149^{f}$ & 15 & 10.1 & 137.8 & 11.2 & 8.1 & 92.5 \\
\hline CB194 & & & & 26.7 & 3.1 & 11.5 & \\
\hline \multicolumn{8}{|l|}{ Pesticides } \\
\hline НСВ & $42^{f}$ & & & 37.1 & 8.1 & 21.9 & 88.3 \\
\hline$p p^{\prime}-\mathrm{DDE}$ & $234^{\mathrm{f}}$ & & & 280.1 & 28.3 & 10.1 & 119.7 \\
\hline
\end{tabular}

${ }^{\text {a }}$ Standard Deviation of certified values

${ }^{\mathrm{b}}$ Relative Standard Deviation of certified values, (SD/mean)*100

c Standard Deviation of experimental values

${ }^{\mathrm{d}}$ Relative Standard Deviation of experimental values, (SD/mean)*100

${ }^{\mathrm{e}}$ Recovery (experimental values / certified values)*100

${ }^{\mathrm{f}}$ Non certified concentrations (Schantz et al., 1993) 
Table 3. Organochlorinated contaminants in the hepatopancreas of male crustaceans from French coastal sites: mean concentrations of CB153

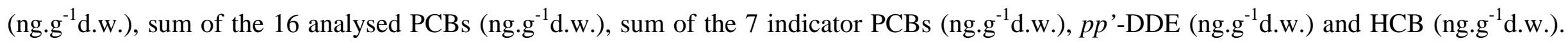
Lipid content (\%) is expressed on a dry weight basis.

\begin{tabular}{|c|c|c|c|c|c|c|c|c|c|}
\hline Site & Species & $\mathrm{N}$ & $\begin{array}{c}\text { Water } \\
\text { content (\%) }\end{array}$ & $\begin{array}{c}\text { Lipid } \\
\text { content (\%) }\end{array}$ & $\begin{array}{c}\text { CB153 } \\
\text { (ng.g }{ }^{-1} \text { d.w.) }\end{array}$ & $\begin{array}{c}\Sigma_{16} \mathrm{PCBs} \\
\text { (ng.g }{ }^{-1} \text { d.w.) }\end{array}$ & $\begin{array}{c}\Sigma_{7} \text { PCBs } \\
\text { (ng.g }{ }^{-1} \text { d.w.) }\end{array}$ & $\begin{array}{c}p p^{\prime}-\mathrm{DDE} \\
\text { (ng.g }{ }^{-1} \text { d.w.) }\end{array}$ & $\begin{array}{c}\text { НCB } \\
\text { (ng.g }{ }^{-1} \text { d.w.) }\end{array}$ \\
\hline \multirow[t]{3}{*}{ Antifer } & Maja brachydactyla & 4 & $64 \pm 4$ & $46.8 \pm 6.1$ & $1271 \pm 433$ & $2976 \pm 905$ & $2335 \pm 741$ & $24.7 \pm 4.4$ & $0.51 \pm 0.21$ \\
\hline & Cancer pagurus & 3 & $65 \pm 8$ & $45.9 \pm 4.3$ & $253 \pm 77$ & $817 \pm 231$ & $617 \pm 169$ & $11.6 \pm 1.9$ & $0.28 \pm 0.09$ \\
\hline & Necora puber & pool & 69 & 40.9 & 594 & 1632 & 1229 & 36.0 & 1,13 \\
\hline \multirow[t]{2}{*}{ Granville } & Maja brachydactyla & 3 & $71 \pm 3$ & $48.2 \pm 4.3$ & $29 \pm 6$ & $77 \pm 11$ & $60 \pm 9$ & $2.2 \pm 0.5$ & $0.67 \pm 0.07$ \\
\hline & Cancer pagurus & 3 & $68 \pm 8$ & $44.1 \pm 5.1$ & $24 \pm 6$ & $68 \pm 15$ & $52 \pm 10$ & $2.2 \pm 0.2$ & $0.36 \pm 0.05$ \\
\hline Roscoff & Maja brachydactyla & 3 & $64 \pm 6$ & $44.8 \pm 7.1$ & $38 \pm 5$ & $101 \pm 4$ & $74 \pm 3$ & $4.5 \pm 0.5$ & $0.72 \pm 0.26$ \\
\hline \multirow[t]{2}{*}{ Le Conquet } & Maja brachydactyla & 5 & $63 \pm 3$ & $47.3 \pm 4.3$ & $148 \pm 21$ & $456 \pm 76$ & $320 \pm 52$ & $3.9 \pm 0.5$ & $0.33 \pm 0.13$ \\
\hline & Cancer pagurus & 5 & $61 \pm 4$ & $46.6 \pm 6.1$ & $60 \pm 22$ & $209 \pm 72$ & $154 \pm 42$ & $4.2 \pm 1.8$ & $0.46 \pm 0.18$ \\
\hline \multirow[t]{2}{*}{ Le Guilvinec } & Maja brachydactyla & 3 & $65 \pm 6$ & $51.3 \pm 5.9$ & $81 \pm 15$ & $251 \pm 52$ & $180 \pm 34$ & $4.6 \pm 1.5$ & $0.83 \pm 0.2$ \\
\hline & Cancer pagurus & 3 & $68 \pm 4$ & $48.8 \pm 3.1$ & $24 \pm 10$ & $77 \pm 28$ & $59 \pm 21$ & $2.4 \pm 0.6$ & $0.33 \pm 0.18$ \\
\hline
\end{tabular}


Table 4. Organochlorinated contaminants in different organs (hepatopancreas, muscle, gonads) of female crustaceans collected at Antifer (A) and Granville (B): mean concentrations of CB153 (ng.g ${ }^{-1}$ d.w.), sum of the 16 analysed PCBs (ng.g ${ }^{-1}$ d.w.), sum of the 7 indicator PCBs (ng.g ${ }^{1}$ d.w.), pp’-DDE (ng.g ${ }^{-1}$ d.w.) and HCB (ng.g ${ }^{-1}$ d.w.). Lipid content (\%) is expressed on a dry weight basis.

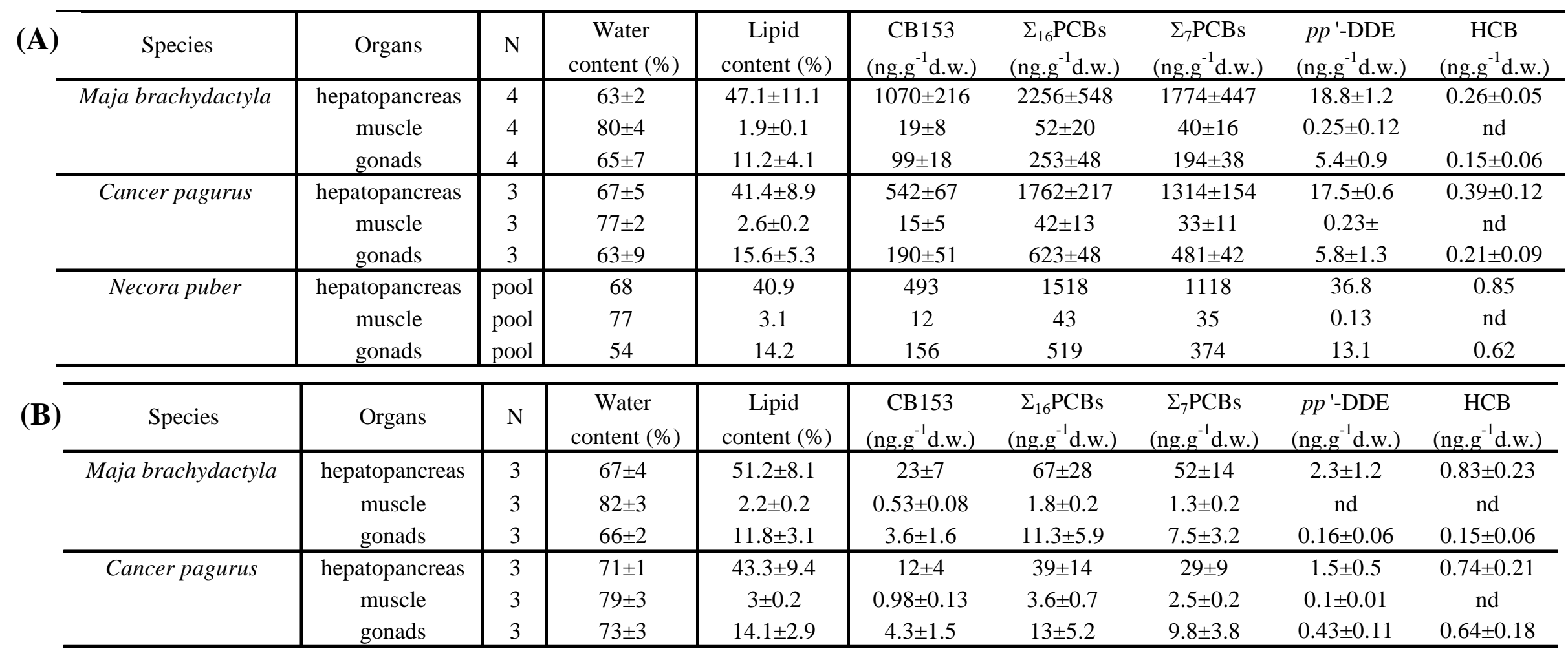



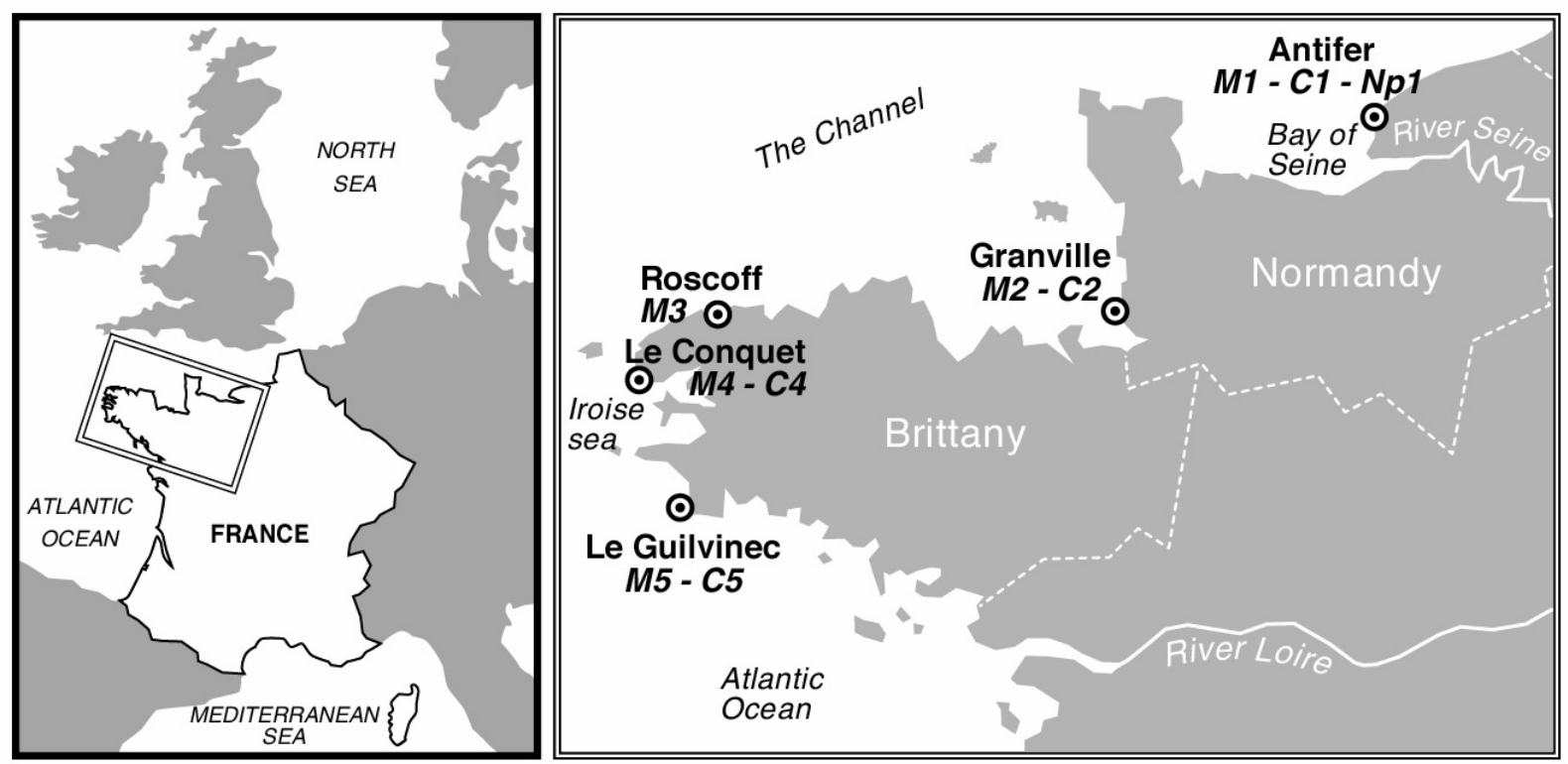

Fig. 47. Map of the studied areas. $\mathrm{M}=$ Maja brachydactyla; $\mathrm{C}=$ Cancer pagurus; $\mathrm{Np}=$ Necora puber. 


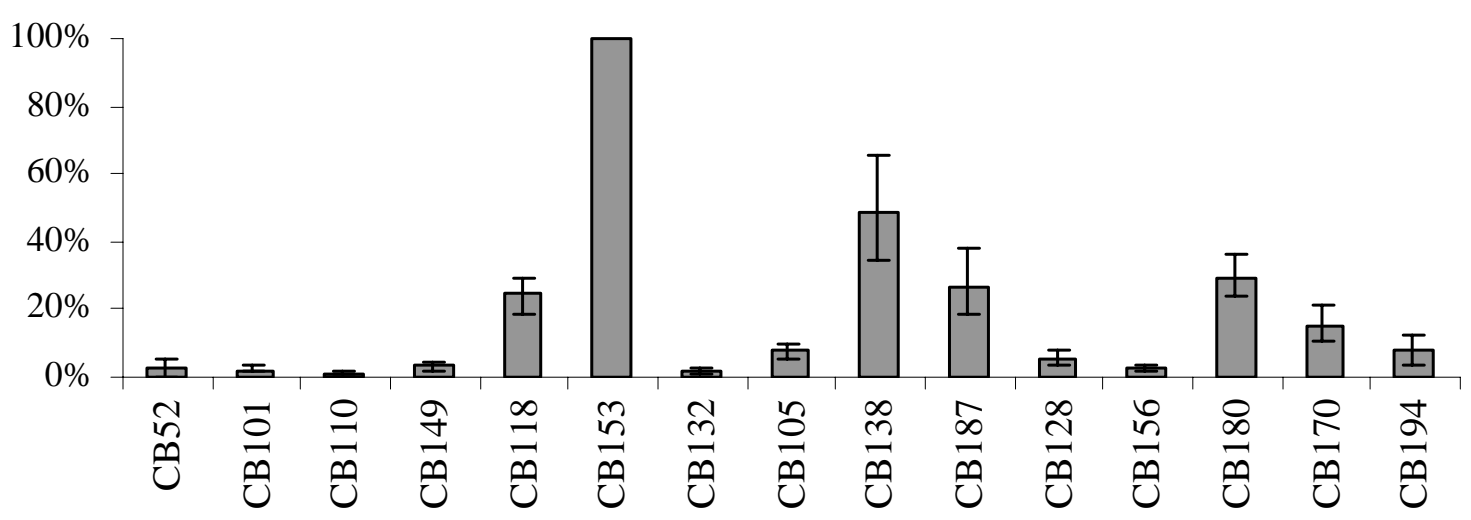

Fig. 48. PCB average pattern in hepatopancreas of male spider crabs from the five sampling sites (Antifer, Granville, Roscoff, Le Conquet and Le Guilvinec). Concentrations of each congener were normalised to $\mathrm{CB} 153(100 \times \mathrm{CBx} / \mathrm{CB} 153)$. Error bars show the range (minimum and maximum) of relative concentrations among the five sampling sites. 


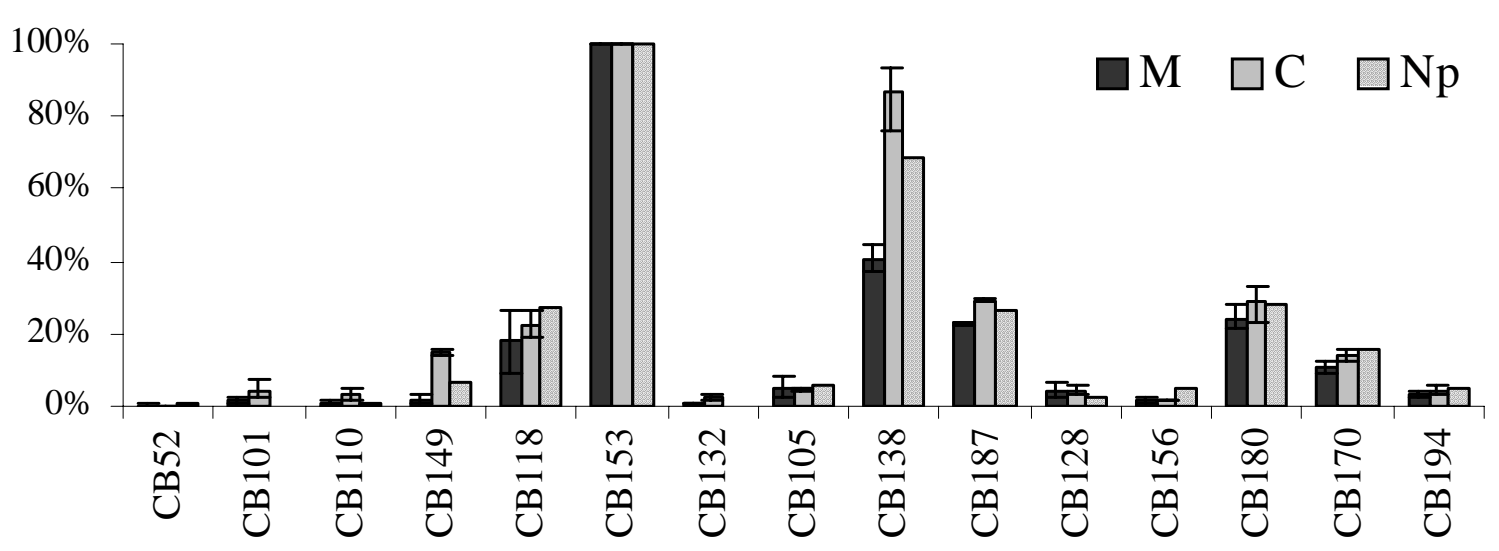

Fig. 49. PCB average patterns in hepatopancreas of male crustaceans from Antifer $(\mathrm{M}=$ Maja brachydactyla; $\mathrm{C}=$ Cancer pagurus; $\mathrm{Np}=$ Necora puber $)$. Concentrations of each congener were normalised to $\mathrm{CB} 153(100 \times \mathrm{CBx} / \mathrm{CB} 153)$. Error bars show the range (minimum and maximum) of relative concentrations for each species. 


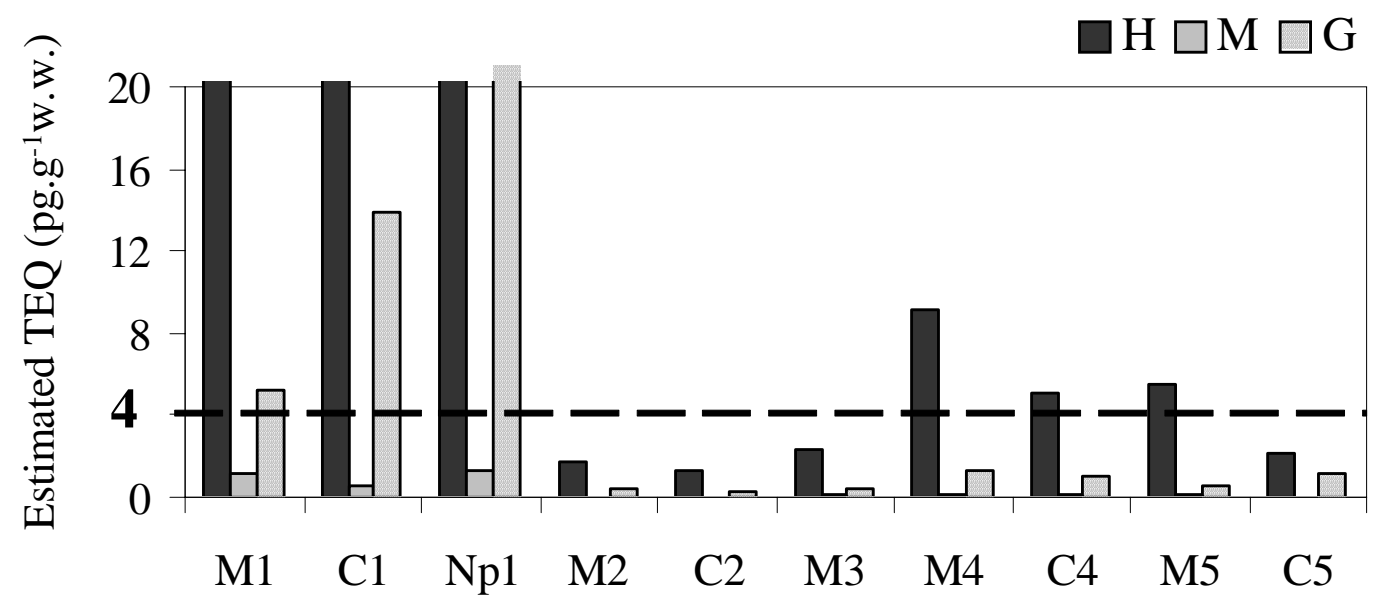

Fig. 50. Estimated TEQ (DL-PCBs) concentrations in organs ( $\mathrm{H}=$ hepatopancreas; $\mathrm{M}=$ muscle; $\mathrm{G}=$ gonads) of various crustacean species $(\mathrm{M}=$ Maja brachydactyla $; \mathrm{C}=$ Cancer pagurus; $\mathrm{Np}$ = Necora puber) from different coastal areas (1-5; see map Fig.1) 